
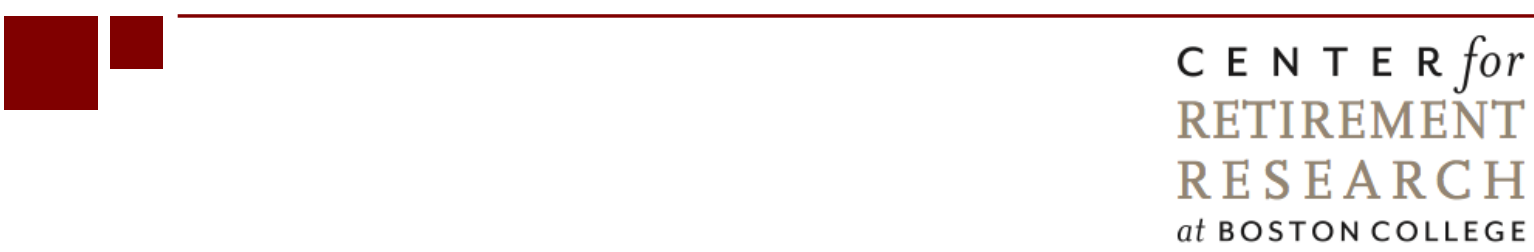

\title{
HOW TO PAY FOR SOCIAL SECURITY'S MISSING TRUST FUND?
}

\author{
Alicia H. Munnell, Wenliang Hou, and Geoffrey T. Sanzenbacher
}

CRR WP 2017-18

December 2017

\author{
Center for Retirement Research at Boston College \\ Hovey House \\ 140 Commonwealth Avenue \\ Chestnut Hill, MA 02467
}

Tel: 617-552-1762 Fax: 617-552-0191

http://crr.bc.edu

All of the authors are with the Center for Retirement Research at Boston College (CRR). Alicia H. Munnell is the Peter F. Drucker Professor of Management Sciences at Boston College's Carroll School of Management and director of the CRR. Wenliang Hou is a senior research advisor. Geoffrey T. Sanzenbacher is associate director of research at the CRR. The research reported herein was performed pursuant to a grant from the U.S. Social Security Administration (SSA) funded as part of the Retirement Research Consortium. The opinions and conclusions expressed are solely those of the authors and do not represent the opinions or policy of SSA, any agency of the federal government, or Boston College. Neither the United States Government nor any agency thereof, nor any of their employees, makes any warranty, express or implied, or assumes any legal liability or responsibility for the accuracy, completeness, or usefulness of the contents of this report. Reference herein to any specific commercial product, process or service by trade name, trademark, manufacturer, or otherwise does not necessarily constitute or imply endorsement, recommendation or favoring by the United States Government or any agency thereof. The authors would like to thank Dean Leimer for extremely helpful comments. Any mistakes are their own.

(C) 2017, Alicia H. Munnell, Wenliang Hou, and Geoffrey T. Sanzenbacher. All rights reserved. Short sections of text, not to exceed two paragraphs, may be quoted without explicit permission provided that full credit, including $(\mathcal{C}$ notice, is given to the source. 


\begin{abstract}
About the Center for Retirement Research
The Center for Retirement Research at Boston College, part of a consortium that includes parallel centers at the University of Michigan and the National Bureau of Economic Research, was established in 1998 through a grant from the Social Security Administration. The Center's mission is to produce first-class research and forge a strong link between the academic community and decision-makers in the public and private sectors around an issue of critical importance to the nation's future. To achieve this mission, the Center sponsors a wide variety of research projects, transmits new findings to a broad audience, trains new scholars, and broadens access to valuable data sources.
\end{abstract}

Center for Retirement Research at Boston College

Hovey House

140 Commonwealth Ave

Chestnut Hill, MA 02467

Tel: 617-552-1762 Fax: 617-552-0191

http://crr.bc.edu

Affiliated Institutions:

The Brookings Institution

Syracuse University

Urban Institute 


\begin{abstract}
Social Security's Trust Fund is projected to run out in 2034. As policymakers consider restoring financial balance to the program, one topic that may be discussed is how to structure any tax increases. Understanding why Social Security requires a higher payroll tax than a funded retirement program for a given level of benefits is a crucial first step in informing this discussion. The current "pay-as-you-go" approach is the result of the policy decision made decades ago to pay benefits far in excess of contributions for early cohorts of workers. By paying benefits in excess of contributions to early cohorts, the nation essentially gave away the Trust Fund that would have accumulated and, importantly, gave away the interest on those contributions. Thus, the payroll tax must cover not only the required contribution but also the missing interest. This paper addresses alternative ways to pay for this Missing Trust Fund, including a comparison of the size of the required changes and their distributional implications.
\end{abstract}

This paper found that:

- The size of the OASI Missing Trust Fund is $\$ 27$ trillion dollars.

- The so-called Legacy Debt - i.e., the $\$ 29.3$ trillion dollar net transfer to pre-1932 birth cohorts - is the driver of this Missing Trust Fund.

- Paying for the missing interest on this Missing Trust Fund could be accomplished with a permanent increase in the capped payroll tax of 3.7 percentage points, in an uncapped payroll tax of 3.0 percentage points, or in the income tax of 2.3 percentage points.

- Accumulating assets to replace the Missing Trust Fund over 75 years requires larger, temporary increases in those taxes of 6.5 percentage points, 5.3 percentage points, and 4.1 percentage points, respectively.

- The burden of a payroll tax increase tends to fall more on households in the middle two income quartiles, whereas the income tax burden falls more on the top quartile.

The policy implications of this paper are:

- The fact that the primary cause of the Missing Trust Fund is the Legacy Debt suggests that increasing the income tax merits consideration, since paying benefits to early program participants benefited all of society. 
- While replacing the Missing Trust Fund would ultimately create a fully funded system with a large, interest-generating Trust Fund, such a move raises macroeconomic issues and questions of intergenerational equity.

- Finding the right approach merits society-wide discussion. 


\section{Introduction}

According to the 2017 Social Security Trustees' Report, Social Security’s Trust Fund is projected to run out in 2034. As policymakers consider restoring financial balance to the program, one topic that may be discussed is how to structure any tax increases. Understanding why Social Security requires a higher payroll tax to provide a given level of benefits than a funded program is a crucial first step in informing this discussion. The current "pay-as-you-go" approach is the result of the policy decision made decades ago to pay benefits far in excess of contributions for early cohorts of workers. By paying benefits in excess of total lifetime contributions to early cohorts, the nation essentially gave away the Trust Fund that would have accumulated and, importantly, the interest on those contributions. This paper addresses the size, implications, and ways to pay for this "Missing Trust Fund." Throughout the paper, the discussion is limited to the implications of the Missing Trust Fund on the funding of the Social Security Program itself. This focus means that this particular paper ignores the effect on the real capital stock of having a pay-as-you-go retirement system, and more broadly on the macroeconomy. ${ }^{1}$

The discussion proceeds as follows. The first section reviews the literature on the magnitude of the Missing Trust Fund and discusses how it relates to the concept of "Legacy Debt." The second section provides estimates of both the Legacy Debt and the Missing Trust Fund that can be easily updated each time the Social Security Trustees Report comes out. The third section lays out alternative paths forward - namely, either putting Social Security on firm financial footing by increasing taxes permanently but maintaining a balanced pay-as-you-go system or increasing taxes by a higher amount temporarily to get to a fully funded system with lower long-term costs. This section also discusses exactly how taxes could be increasedthrough increasing the payroll tax rate alone; increasing the payroll tax rate along with eliminating the payroll tax cap; or increasing the income tax. The fourth section explores the distributional and welfare implications of the various approaches. The final section concludes that the distributional impacts and political implications of using the income tax to cover the "missing interest" merit society-wide discussion.

\footnotetext{
${ }^{1}$ For an excellent discussion of these issues and citations to other relevant work, see Leimer (2016).
} 


\section{The Size of the Missing Trust Fund}

With the exception of the buildup of reserves in the wake of the 1983 amendments and the imminent depletion of these reserves, Social Security has generally been financed on a payas-you-go basis. This funding method differs sharply from the original 1935 legislation, which set up a plan that bore a much stronger resemblance to a private insurance plan, with the accumulation of a Trust Fund and the close alignment of contributions and benefits for any given cohort. The 1939 amendments, however, fundamentally changed the nature of the program. These amendments tied benefits to average earnings, initially over a minimum period of coverage, and added spousal and survivor benefits that were effectively unfunded, thus breaking the link between lifetime contributions and benefits. These changes meant that in the early stages of the program, payroll tax receipts were used to pay benefits to retirees far in excess of their contributions rather than to build up a Trust Fund. ${ }^{2}$

The simplest way to see the implications of Social Security's Missing Trust Fund is to consider the contribution rate required to finance Social Security retirement benefits under a funded retirement plan compared to a pay-as-you-go system (this paper excludes discussion of Disability Insurance). Under a stylized model of a funded retirement system, with the Social Security Trustees' intermediate assumptions on mortality and on the real interest rate (2.7 percent), to achieve a replacement rate of approximately 36 percent (the projected Social Security replacement rate for the average earner once the Full Retirement Age equals age 65), the typical worker would have to contribute about 10.6 percent of earnings. ${ }^{3}$ Under a pay-as-you go system with a projected ratio of two workers for each retiree and annual real wage growth of 1.2 percent, a 36-percent replacement rate would require a contribution rate of 14.3 percent. The resulting 3.7-percentage-point (14.3 percent versus 10.6 percent) difference in the required payroll tax in these two stylized models is due to the presence of a Trust Fund that can pay interest in a fully funded system but that is "missing" in the pay-as-you-go system.

This "Missing Trust Fund" exists for two reasons: 1) early cohorts were paid much more than they contributed; and 2) that amount could not be made up by subsequent birth cohorts (and in some cases has been added to). The part of the Missing Trust Fund created specifically by

\footnotetext{
${ }^{2}$ The story of Ida Mae Fuller is an extreme example. Ms. Fuller had worked under Social Security for less than three years when she became the first person to claim monthly benefits. She died at age 100, after receiving benefits for 35 years. She clearly enjoyed an extraordinary rate of return on her contributions to the system.

${ }^{3}$ See Appendix A for the calculation used in this estimate.
} 
paying early cohorts more than they contributed is often referred to as the Legacy Debt. As an actuarial concept, Legacy Debt is the difference with interest between a set of birth cohorts' contributions to Social Security and their benefits received. Whether or not the Legacy Debt exists in real terms, i.e., that future generations will have less income or a lower capital stock because of it, is unclear because the transfers to earlier generations could result in extra economic activity that offsets the debt. Leimer (2016) provides a discussion of this issue, but as was discussed above, this current paper is strictly focused on the implications of the Legacy Debt as an actuarial construct on the program's finances.

The size of the Legacy Debt varies based on the birth cohorts used in the calculation - for example, Leimer (2016) estimates a Legacy Debt of \$24.4 trillion as of 2014 for birth cohorts born through 1931 and \$20.9 trillion for those born through 1949. The lower number through 1949 reflects the fact that cohorts born between 1932 and 1949 are expected to make positive net transfers to the program under current law. Estimates of the Legacy Debt also change with time as the interest that would have accrued on those early cohorts' contributions into the Trust Fund grows. For example, Leimer (2007) found lower Legacy Debt estimates of \$13.0 and \$11.2 trillion through the 1931 and 1949 birth cohorts respectively as of 2001; and the only difference between his 2007 and 2016 estimates is the accumulated interest. ${ }^{4}$

The above discussion highlights the fact that estimates of the Legacy Debt can change as more birth cohorts are added - going up or down depending on that birth cohort's net transfer from the program. The implication is that the Legacy Debt - which reflects a specific notion of paying early recipients more than they contributed - is not identical to the Missing Trust Fund, because later birth cohorts can replace some of that missing fund if they contribute more into the program than they are projected to receive (as did those born between 1932 and 1949), or they can add to the deficit. A concept that reflects these later transactions is the "Closed Group Unfunded Obligation," calculated each year by Social Security's Office of the Chief Actuary. ${ }^{5}$

The Closed Group Unfunded Obligation equals the difference between the present value of projected program costs and the present value of projected contributions for all current participants minus the size of the existing Trust Fund. In other words, the Closed Group

\footnotetext{
${ }^{4}$ Other estimates are available in Leimer (1994), Geanakoplos, Mitchell, and Zeldes (1998, 1999, and 2000), and Diamond and Orszag (2005).

${ }^{5}$ The most recent estimate from Nickerson and Burkhalter (2017) is \$30.8 trillion for the OASDI program.

Nickerson and Burkhalter do not provide estimates separately for OASI only.
} 
Unfunded Obligation is calculated in the same way as the Legacy Debt, but simply includes any birth cohort with individuals still under age 116 (the maximum age of life Social Security assumes) and over age 15. ${ }^{6}$ The Closed Group Unfunded Obligation is our measure of the Missing Trust Fund, since it reflects the money that would need to be transferred to the Trust Fund to offset the entirety of the Legacy Debt plus (or minus) the amounts for any subsequent birth cohorts where the present value of benefits paid exceeded (or fell short of) that cohort's contributions. $^{7}$

\section{Creating an Easily Updated Tool for the Legacy Debt and the Missing Trust Fund}

The two components of the Missing Trust Fund - the Legacy Debt and the net transfers by more recent cohorts - can be linked through a "tool" to illustrate the role that the Legacy Debt plays in today's Missing Trust Fund. The output of this tool can be easily updated each time a Social Security Trustee's Report is released and can serve as the basis for a discussion of various approaches for improving Social Security's finances with a clear view of the financial shortfall's origin.

For each birth cohort, the tool requires two values: 1) the net present value of the cohort's contributions to Social Security through the payroll tax; and 2) the net present value of the cohort's Social Security benefits. Social Security provides projections of both contributions and benefits paid, but it does not provide these data by birth cohort. Cohort data could be calculated with individual data on earnings and benefits paid, but that information is difficult to access and thus hard to use to update calculations regularly. Furthermore, even if the actual individual-level data were available, estimates of any Missing Trust Fund will change each year as the projected contributions and benefits of today's participants are updated. Given these difficulties, the

\footnotetext{
${ }^{6}$ In practice, the Closed Group Unfunded Obligation reported by the Social Security Administration also includes Trust Fund components other than contributions and benefits, such as administrative costs, whereas Legacy Debt calculations typically do not. Also, even though cohorts born before 1900 are not explicitly included in the calculation of the Closed Group Unfunded Obligation, their net receipt from the program shows up through the fact that the Trust Fund is smaller than it would be otherwise.

${ }^{7}$ The Open Group Unfunded Obligation is a related measure and includes the projected gap between benefits and payments for all future workers as well. Due to increasing life expectancies without a corresponding increase in the Full Retirement Age, this measure is slightly higher than the Closed Group Unfunded Obligation. This paper focuses on the Closed Group to measure the Missing Trust Fund because it seems more appropriate given the backward-looking concept used in this paper.
} 
sections below discuss how these quantities can be calculated from readily-available data and projections.

\section{Net Present Value of Contributions}

To calculate the net present value of a birth cohort's contributions, the starting point is Social Security's information on historical data and projections for payroll contributions. ${ }^{8}$ The next step is to divide these contributions up among the relevant birth cohorts. This task is accomplished by using data on annual taxable earnings from the Current Population Survey (CPS) and calculating the share of total earnings in the sample due to individuals from each birth cohort. For example, in 1980, taxable payroll contributions to OASI were just over $\$ 103$ billion. If, in the 1980 CPS, 25-year-olds represented 2 percent of taxable payroll, then the 1955 birth cohort (1980 - 25) would be assigned contributions of $\$ 2.1$ billion $(\$ 103.0 * 0.02)$. In this way, each birth cohort is assigned its estimated share of total contributions. For future contributions, the share of payroll coming from each age is held constant at the 2016 level with the level of payroll based on Social Security's projections. Figure 1 shows the estimated present value of payroll contributions by birth cohort. ${ }^{9}$ Lifetime contributions were low for early program participants before ramping up for birth cohorts that spent the entirety of their working lives contributing.

\section{Net Present Value of Benefits}

Calculating the net present value of benefits for a given cohort is slightly more complicated. Once again, the starting point is Social Security's historical data on benefits and its projections. The benefits of any one birth cohort are based on the aggregate difference in benefits paid from one year to the next. ${ }^{10}$ If no new cohort entered the program, then the benefits paid would grow (or shrink) based on the original cohorts' cost-of-living adjustments and rate of

\footnotetext{
${ }^{8}$ Historical contributions are available in Table VI.A.1 of the 2016 Social Security Trustees Report, "Operations of the OASI Trust Fund, Calendar Years 1937-2015." Projections on taxable payroll are available from Table IV.B.1 of the 2016 Social Security Trustees Report, "Annual Income Rates, Cost Rates, and Balances, Calendar Years 1990-2090," and Table VI.G6, "Selected Economic Variables, Calendar Years 1970-2090."

${ }^{9}$ Appendix B offers more detail and a discussion of how these estimated contributions compare to those of Leimer (2007), who used individual level historical data combined with Trustees Report projections.

${ }^{10}$ Historical benefits are available in Table VI.A.1 of the 2016 Social Security Trustees Report, "Operations of the OASI Trust Fund, Calendar Years 1937-2015." Projections on benefits are available from Table IV.B.1 of the 2016 Social Security Trustees Report, "Annual Income Rates, Cost Rates, and Balances, Calendar Years 1990-2090,"
} 
mortality. ${ }^{11}$ Any upward departure from this calculated trend would reflect the new benefits being paid to the entering birth cohort. ${ }^{12}$ The next year, this process can be repeated for the next entering cohort. This iterative process requires a starting point where the contributions of a given birth cohort are known with certainty. For this starting point, we use the 1901 birth cohort for which Leimer (2007) had individual-level data. Figure 2 shows the estimated present value of benefits received by birth cohort. ${ }^{13}$

\section{The Current Size and Composition of the Missing Trust Fund}

The discussion above makes clear that the data contained in Figures 1 and 2 can be differenced to calculate the net transfer for any given birth cohort. For example, the 1910 birth cohort made lifetime contributions with a net present value of about $\$ 180$ billion (in 2016 dollars), but received benefits of about $\$ 1,097$ billion. The result is a net transfer of about $\$ 917$ billion dollars.

In turn, these net transfers can be added together to get estimates of the Legacy Debt Component of the Missing Trust Fund or of the Missing Trust Fund in its totality. ${ }^{14}$ Figure 3 shows the net transfer (benefits minus contributions) for each birth cohort between 1901 and 2001 (the last birth cohort included in the closed group), as well as the cumulative sum of all of these net transfers. ${ }^{15}$ The figure clearly illustrates that early birth cohorts received large positive transfers and that birth cohorts affected most by the 1983 amendments are projected to receive negative net transfers, even under current law. For more recent birth cohorts, it is hard to read too much into the net transfers, since current revenues are inadequate to pay promised benefits over the next 75 years.

The major point is that under current law, although more recent birth cohorts' have tended to have negative or zero net transfers, these alone have not been enough to offset the Legacy Debt. By this paper's estimates, the Legacy Debt through 1931 for the OASI program

\footnotetext{
${ }^{11}$ The current project focuses on Social Security retiree and spousal benefits, and ignores auxiliary benefits to children.

${ }^{12}$ In practice, this requires an assumption on claiming, which is assumed to occur at age 65 . Because the actuarial adjustment is approximately fair at today's interest rate, this assumption is not critical.

${ }^{13}$ Appendix B offers more detail and a comparison to Leimer (2007).

${ }^{14}$ Excluding Trust Fund components aside from benefits and contributions, like administrative costs.

${ }^{15}$ Birth cohorts prior to 1901 contributed $\$ 9.0$ trillion of negative, cumulative net transfers.
} 
stands at $\$ 29.3$ trillion. ${ }^{16}$ The net negative transfer experienced by the 1932-2001 birth cohorts under current law was just \$2.3 trillion, leading to a Closed Group Unfunded Obligation of \$27.0 trillion for the OASI program ( $\$ 29.3$ trillion -2.3 trillion). In other words, more than the entirety of the Missing Trust Fund is due to the "Legacy Debt." ${ }^{17}$ This Missing Trust Fund makes the program more costly than it otherwise would be, as current participants are forced to contribute towards both benefits and the missing interest. How much it would cost to deal with this Missing Trust Fund is the subject of the next section.

\section{Dealing with the Missing Trust Fund}

Broadly, two ways exist to deal with Social Security's financial shortfall. The first is simply to replace the missing interest, roughly holding constant the present value of the Missing Trust Fund going forward. To implement this approach, the revenue coming into the program would need to be increased permanently. Under a missing interest approach, future cohorts of participants would receive negative net transfers from the program due to the lack of interest their own contributions accrue. Indeed, some might argue that a negative transfer is fair because of the various forms of insurance Social Security provides (e.g., wage and longevity) and that are not available in other assets people can buy on their own.

An alternative approach would be to increase taxes by a higher amount but only temporarily, until a Trust Fund consistent with a fully funded program is built up. This buildup could be accomplished over a short time horizon with a larger tax increase or over a longer period with a smaller tax increase. In any case, once this Trust Fund is built up, the accrued interest will allow a return to roughly today's level of the payroll tax, which - as discussed earlier - is consistent with a fully funded system given the current level of benefits. Birth cohorts who face the tax increase will receive negative net transfers from the program, but future cohorts will experience a lower cost program due to the existence of a Trust Fund that generates interest on contributions.

\footnotetext{
${ }^{16}$ The 1931 birth cohort was chosen as the last cohort included in the Legacy Debt calculation to be consistent with Leimer (2007), who found that the Legacy Debt of the OASI program hit a maximum at that cohort. In the current paper, the Legacy Debt hits its maximum slightly later.

${ }^{17}$ Again, ignoring other Trust Fund components like administrative costs.
} 
Within these two broad approaches, alternative ways exist to actually implement the required tax increases. The most obvious way is simply to increase the payroll tax by the required amount, maintaining the current cap of \$127,200 (adjusted annually for wage growth). A second approach is to combine a payroll tax increase with an expansion of the tax base by eliminating the payroll tax cap completely. (The calculations below assume that contributions made over the current cap do not generate benefits.) A third approach is to shift some reliance from the payroll tax to the income tax to reflect the fact that the Missing Trust Fund is a function of the policy decision to pay early beneficiaries more than they contributed. One could argue that these additional costs should not be borne solely by workers, but instead include individuals who earn their income from sources other than labor.

Table 1 shows how large these tax increases would have to be to pay for the missing interest or replace the Missing Trust Fund entirely over a time horizon of 75 to 150 years. The table makes clear that replacing the Missing Trust Fund requires a larger tax increase than does simply paying the missing interest and that expanding the tax base - either by taxing earnings over the cap or by using the income tax requires a smaller rate increase. For example, the required increase in the capped payroll tax is 3.7 percentage points to pay the missing interest indefinitely and 6.5 percentage points to replace the Missing Trust Fund in 75 years, compared to 3.0 and 5.3 percentage points if the cap is eliminated. Expanding the tax base even further and using the income tax lowers these amounts to 2.3 percentage points and 4.1 percentage points respectively. Aside from the level of taxation required, the various approaches would affect individuals across the income distribution differently. The next section turns to this issue.

\section{The Distributional Effect of Dealing with the Missing Trust Fund}

To analyze the distributional effect of various policies to deal with the Missing Trust Fund, this paper uses NBER's TaxSim program in conjunction with the Survey of Consumer Finances (SCF). To run the SCF data through the TaxSim program, it is necessary to code 22 variables into the required format. These include standard variables like age, the state of residence, marital status, and the number of dependent children under age 19. The program also requires information on the respondents' and their spouses' income from wages and salary. Several other sources of household income must be included as well, including: dividends, property income, income from pensions, income from Social Security benefits, and income from transfers. Adjustments are allowed for rent paid (which affects property tax rebates), medical 
expenses, child care expenses, mortgage interest, and capital gains and losses. Once these variables are appropriately coded, they can be run through the program, which then outputs the individual's income and FICA tax liability. These amounts can then be adjusted to see how different ways of addressing the Missing Trust Fund impact households at different points in the income distribution. For purposes of the analysis, households are divided into four quartiles based on their current income.

Table 2 shows how the incremental taxes paid are distributed by income quartile under the three approaches. The capped payroll tax increase tends to be the most evenly distributed, the uncapped payroll tax next, and the income tax brings in the highest share from the top quartile.

But while the share of taxes paid is uniformly higher for the highest income quartile, the actual burden of the taxes on households' budgets tends to fall more heavily on households further down the economic ladder for the two types of payroll tax increases (see Table 3). ${ }^{18}$ The effect of the increases differs considerably across non-workers and households with at least one worker. An increase in the payroll tax falls hardest on the working households in the two middle quartiles because most of their income comes from earnings and all of their earnings falls under the payroll tax cap. For workers in the top quartile, the effect of the payroll tax increase is roughly half as large since much of their income from work lies above the cap and many have sources of income beyond work. For working households in the bottom quartile, the effect of the payroll tax is mitigated because many households in the lowest quartile do not work. The pattern is similar both for paying missing interest and for replacing the Missing Trust Fund, although the burden on household budgets increases proportionately for replacing the Missing Trust Fund.

Expanding the payroll tax by eliminating the cap spreads the burden more equally for working households, with households in all quartiles paying between 2.2 percent and 2.7 percent of their total income in tax for the policy option of paying missing interest only. The highest quartile is the only group to see an increased share of their household income devoted to the tax increase under this policy compared to the alternative of simply raising the capped payroll tax. By comparison, the income tax shifts more of the burden to the highest quartile. Under an increase in the income tax that would pay for the missing interest, the median household

\footnotetext{
18 The results for other time horizons are similar, but proportionately higher, than the result for 75 years.
} 
(including those households with and without wage and salary workers) in the top quartile would pay about 2.0 percent of their income to the payroll tax, the second quartile 0.9 percent, while the third quartile would pay just 0.3 percent and the median household in the lowest quartile would pay nothing. Again, the results are proportionately higher for tax increases that would replace the Missing Trust Fund but they follow a similar pattern.

Of course, looking at the reduction in household income is only one way to consider the distributional effects of this kind of policy. Another would be to consider the reduction in household utility. In general, because households are risk averse, a loss in income for poor households is worse than a loss of income for rich households. Essentially, risk aversion means household utility functions are non-linear and concave - a movement towards less income costs more in utility terms than the same size movement towards more income adds. This difference is exaggerated at lower incomes. A commonly used utility function that captures the notion of risk aversion is:

$$
u\left(c_{h}\right)=\frac{c_{h}^{1-\gamma}}{1-\gamma}
$$

Where $c_{h}$ indicates a household's consumption and $\gamma$ is the coefficient of relative risk aversion. Basically, the higher $\gamma$, the more extreme is the lost utility relative to the gain for similar-sized reductions or increases in income.

Tables $4 \mathrm{a}$ and $4 \mathrm{~b}$ show the reduction in household utility across the three tax increases for the commonly used values of $\gamma=2$ and $\gamma=3$ respectively. The results show the disproportionate effect of a payroll tax increase on the middle two quartiles. This disproportionate increase exists regardless of whether $\gamma$ equals 2 or 3 and whether taxes pay for the missing interest or to build up assets. Put simply, a payroll tax increase disproportionately burdens households with at least one worker in the bottom three quartiles, particularly when utility is considered instead of simply income. With an income tax, the effect is moderated greatly for the bottom three quartiles, with the highest quartile paying a larger share of its income than under any of the other tax schemes.

\section{Cohort Effects}

The analysis above examined a single point in time and showed that replacing the Missing Trust Fund has a higher impact on household budgets than simply paying for the 
missing interest. Two points that relate to the cost of these tax increases over time also merit consideration. Paying the missing interest requires a smaller increase today but that increase lasts forever, while replacing the Missing Trust Fund requires a larger increase today but for a limited period of time. Using the example of a capped payroll tax increase, Figure 4 shows how these two approaches affect the net transfer received by birth cohorts going forward. Paying off the missing interest (see "Interest only" plot) starting today means birth cohorts currently working receive a reduction in their net lifetime transfer related to their remaining time in the workforce (e.g., a 25-year-old gets a bigger reduction than a 55-year-old), with birth cohorts after 2001 having the largest impact because they spend their entire career under the higher payroll tax. ${ }^{19}$ On the other hand, replacing the Missing Trust Fund in 75 years has an immediately larger effect on current workers, with the most substantial effect on birth cohorts born between 2002 and 2026 who spend their entire careers in the higher payroll tax regime. The birth cohort born in 2027 would be working in 2091 at age 64, when taxes can be reduced to 10.6 percent, with every birth cohort after that spending an increasingly smaller share of their careers in the higher tax regime. Eventually, future cohorts exist in a "fully funded" system where net contributions and transfers are essentially equal.

Another issue worth considering is the cost of waiting until the Trust Fund runs out in 2034. By 2034, the Missing Trust Fund will be equal to $\$ 54.5$ trillion dollars, mostly due to the accumulation of interest between now and then, which will require a payroll tax increase of 4.0 percentage points to pay for the missing interest (compared to 3.7 percentage points if enacted today). Figure 4 clearly illustrates that the actual cost of increasing taxes is nuanced - many current cohorts end up paying a reduced amount, but future cohorts have to pay a little bit more. While Tables 2 through 4 show that the type of tax used has different distributional impacts across different income groups today, Figure 4 shows that the timing and the approach of paying for the Missing Trust Fund also has distributional implications across birth cohorts.

\section{Conclusion}

This paper shows that the so-called "Missing Trust Fund" is mostly a result of "Legacy Debt" built up during the early years of the Social Security. These origins suggest that - if the

\footnotetext{
19 The upward trend visible in Figure 4 across all three tax schemes has to do with projected improvements in longevity that are not made up for by an increase in the Full Retirement Age under current law.
} 
goal were to maintain benefits at current-law levels - policymakers might want to consider a variety of ways to structure a revenue increase, ranging from an increase in the payroll tax without an expansion of its base, to a smaller increase in the payroll tax with an expansion of its base, to an increase in the income tax. Taxing the society more widely - through an income tax increase - could make sense given that society as a whole benefitted from having a generation of people receive benefits who did not fully contribute to the system. Any of these taxes could be raised permanently by a moderate amount, effectively paying the missing interest from the Missing Trust Fund, or by a larger amount, ultimately replacing the Missing Trust Fund before returning taxes to their current level.

The distributional effect of each policy is clear. Increasing the payroll tax tends to place a disproportionate burden on middle class working households, whether that burden is measured by reduced household income or by reduced utility. Getting rid of the payroll tax cap distributes some of that burden onto the top quartile, but the effect on middle class workers is still fairly substantial. Increasing the income tax, on the other hand, places more of the burden on the top quartile. The distributional impacts of replacing the Missing Trust Fund versus simply paying for its interest also raise the question of intergenerational equity - burdening today's workers for a lower cost program tomorrow.

But although the distributional effect of each policy is clear, deciding on the "right" approach is well outside the scope of this paper. Instead, the point of this paper is simply to make clear which types of tax increases and approaches are available and what the distributional effects could be. 


\section{References}

Diamond, Peter A. and Peter R. Orszag. 2005. "Saving Social Security." Journal of Economic Perspectives 19(2): 11-32.

Feenberg, Daniel and Elisabeth Coutts. "TaxSim.” Cambridge, MA: National Bureau of Economic Research."

Geanakoplos, John, Olivia S. Mitchell, and Stephen P. Zeldes. 1998. "Would a Privatized Social Security System Really Pay a Higher Rate of Return?” In Framing the Social Security Debate, edited by R. Douglas Arnold, Michael J. Graetz, and Alicia H. Munnell, 137156. Washington, DC: Brookings Institution Press.

. 1999. "Social Security Money's Worth.” In Prospects for Social Security Reform, edited by Olivia S. Mitchell, Robert J. Myers, and Howard Young, 79-151. Philadelphia, PA: University of Pennsylvania Press.

. 2000. "Would a Privatized Social Security System Really Pay a Higher Rate of Return.” Working Paper 6713. Cambridge, MA: National Bureau of Economic Research.

Leimer, Dean R. 1994. "Cohort-Specific Measures of Lifetime Net Social Security Transfers." ORS Working Paper Series 59. Washington, DC: U.S. Social Security Administration, Office of Research and Statistics.

. 2007. "Cohort-Specific Measures of Lifetime Social Security Taxes and Benefits." ORES Working Paper Series 110. Washington, DC: U.S. Social Security Administration, Office of Research, Evaluation, and Statistics.

. 2016. "The Legacy Debt Associated with Past Social Security Transfers." Social Security Bulletin 76(3): 1-15.

Nickerson, Daniel and Kyle Burkhalter. 2017. "Unfunded Obligation and Transition Costs for the OASDI Program.” Actuarial Note 2017.1. Baltimore, MD: U.S. Social Security Administration, Office of the Chief Actuary.

U.S. Board of Governors of the Federal Reserve System. Survey of Consumer Finances, 2013. Washington, DC.

U.S. Social Security Administration. 2000-2017. The Annual Reports of the Board of Trustees of the Federal Old-Age and Survivors Insurance and Federal Disability Insurance Trust Funds. Washington, DC: U.S. Government Printing Office. 
Figure 1. Present Value of Payroll Tax Contributions by Birth Cohort under Current Law, 2016 Dollars

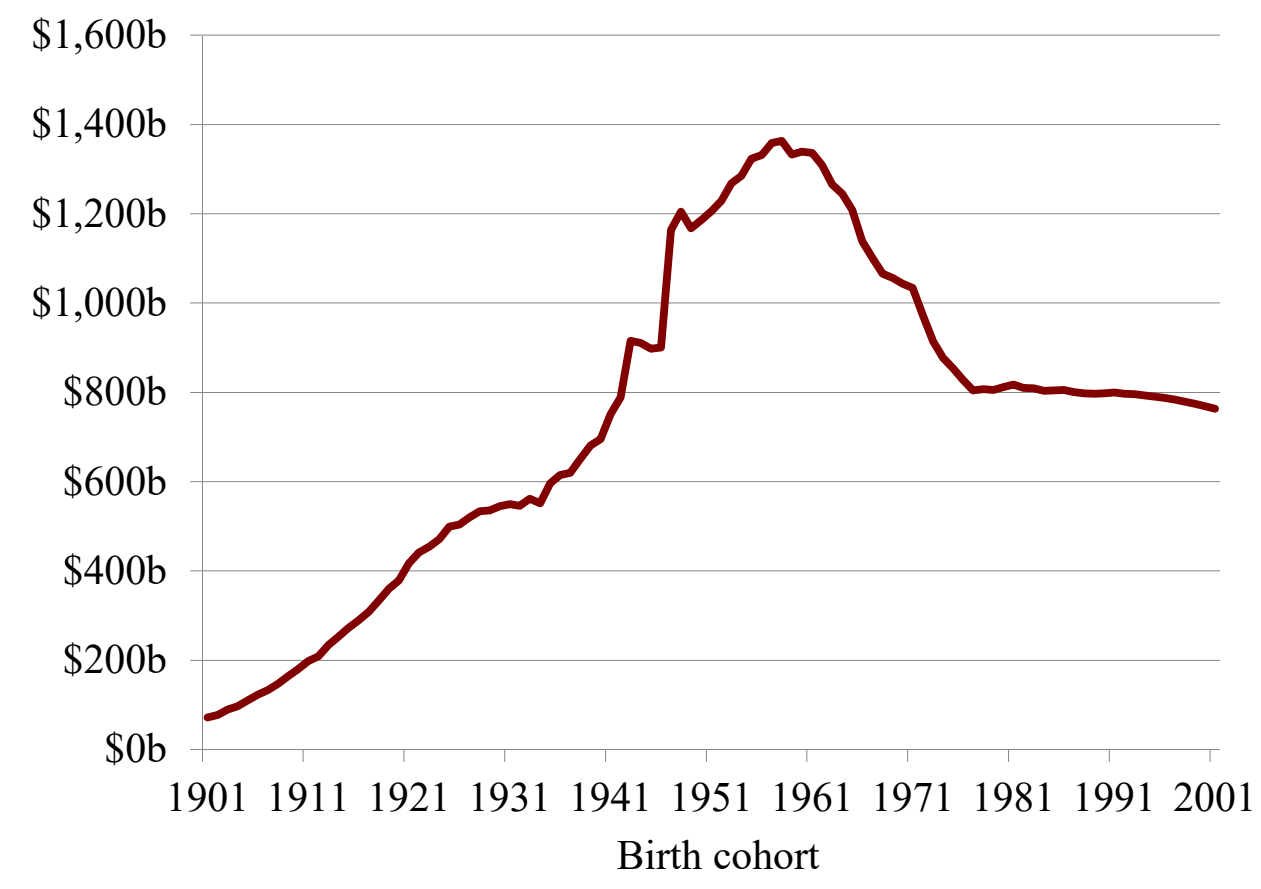

Sources: 2017 Social Security Trustees Report; and authors' calculations.

Figure 2. Present Value of Benefits by Birth Cohorts under Current Law, 2016 Dollars

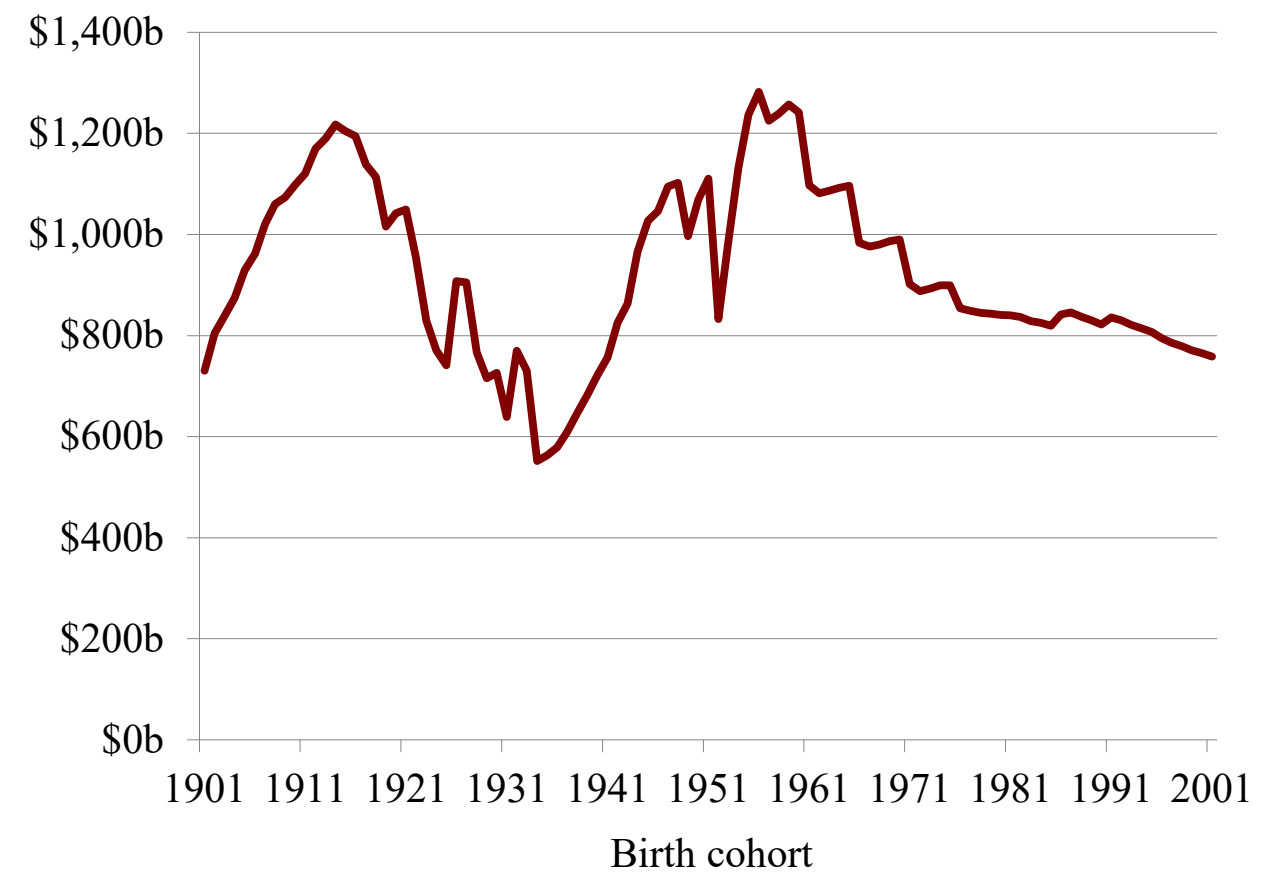

Sources: 2017 Social Security Trustee’ Report; and authors' calculations. 
Figure 3. Net Transfer and Cumulative Net Transfer under Current Law by Birth Cohort, 2016 Dollars

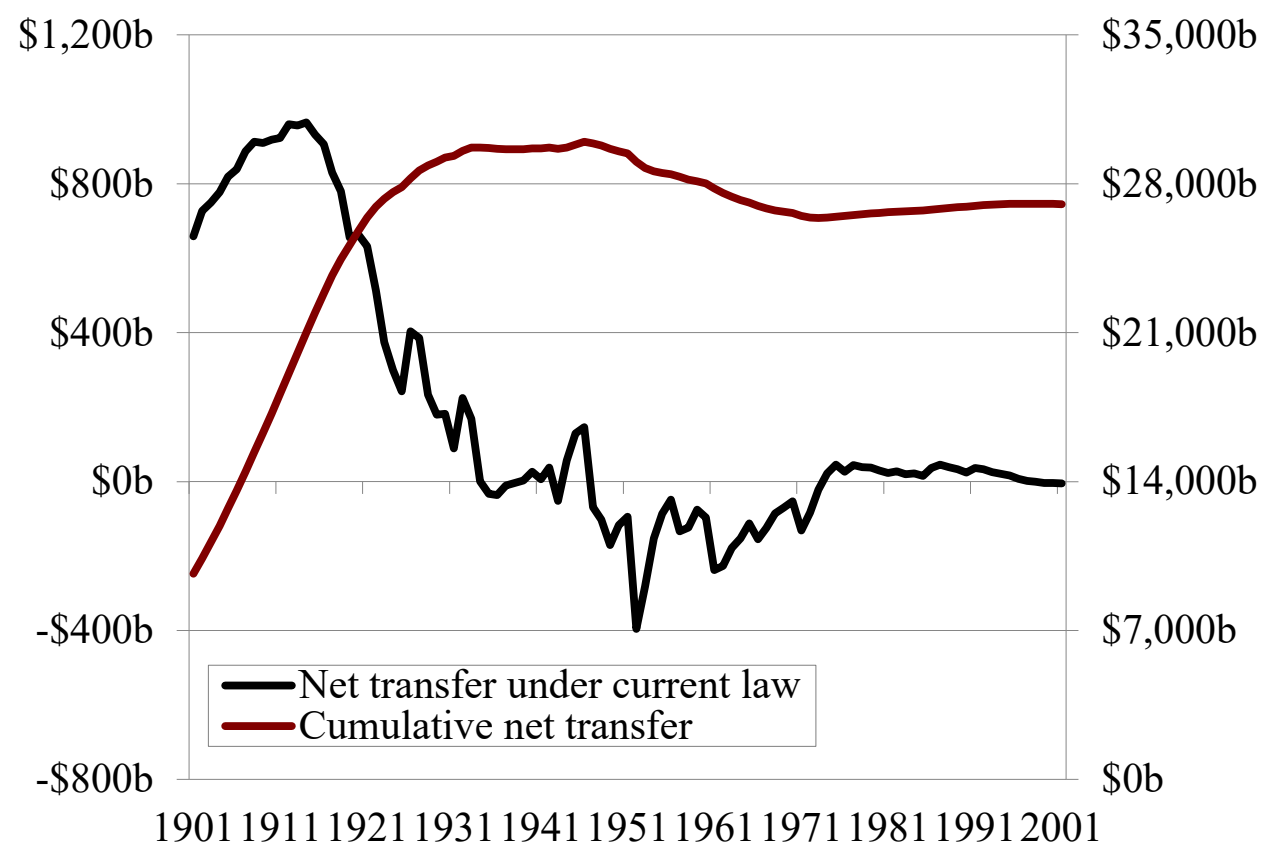

Note: "Cumulative net transfer" includes $\$ 9.0$ trillion to pre-1901 birth cohorts.

Sources: 2017 Social Security Trustees Report; and authors' calculations.

Figure 4. Net Transfer under Current Law and Alternative Revenue Scenarios by Birth Cohort, 2016 Dollars

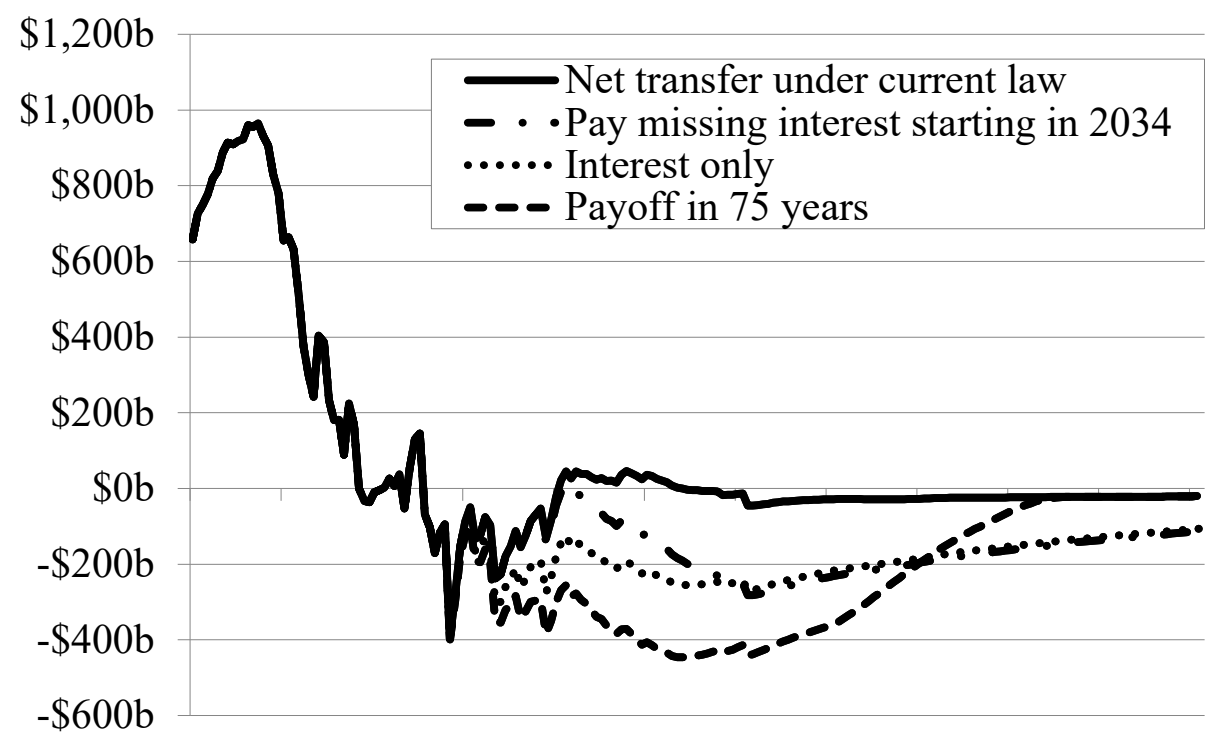

190119191937195519731991200920272045206320812099

Birth cohort

Sources: 2017 Social Security Trustees Report; and authors' calculations using the Survey of Consumer Finances (SCF), 2013 and Feenberg and Coutts ("TaxSim"). 
Table 1. Required Percentage-Point Increases in Taxes to Finance Missing Trust Fund

\begin{tabular}{lccc}
\hline & Payroll tax & Eliminate cap & Income tax \\
\hline Pay back interest only & $3.7 \%$ & $3.0 \%$ & $2.3 \%$
\end{tabular}

Replace missing Trust Fund in:

\begin{tabular}{llll}
150 years & 4.5 & 3.7 & 2.8 \\
125 years & 4.8 & 4.0 & 3.0 \\
100 years & 5.4 & 4.5 & 3.4 \\
75 years & 6.5 & 5.3 & 4.1 \\
\hline
\end{tabular}

Sources: 2017 Social Security Trustees Report; and authors' calculations.

Table 2. Share of Tax Increases Paid, by Income Quartile under Policy Alternatives

\begin{tabular}{lccc}
\hline & Payroll tax & Eliminate cap & Income tax \\
\hline Top quartile & $54 \%$ & $65 \%$ & $84 \%$ \\
Second quartile & 29 & 22 & 12 \\
Third quartile & 13 & 10 & 4 \\
Lowest quartile & 4 & 3 & 1 \\
\hline
\end{tabular}

Sources: 2017 Social Security Trustees Report; and authors' calculations using the 2013 SCF and Feenberg and Coutts ("TaxSim").

Table 3. Share of Household Income Used to Pay Tax Increases, by Income Quartile

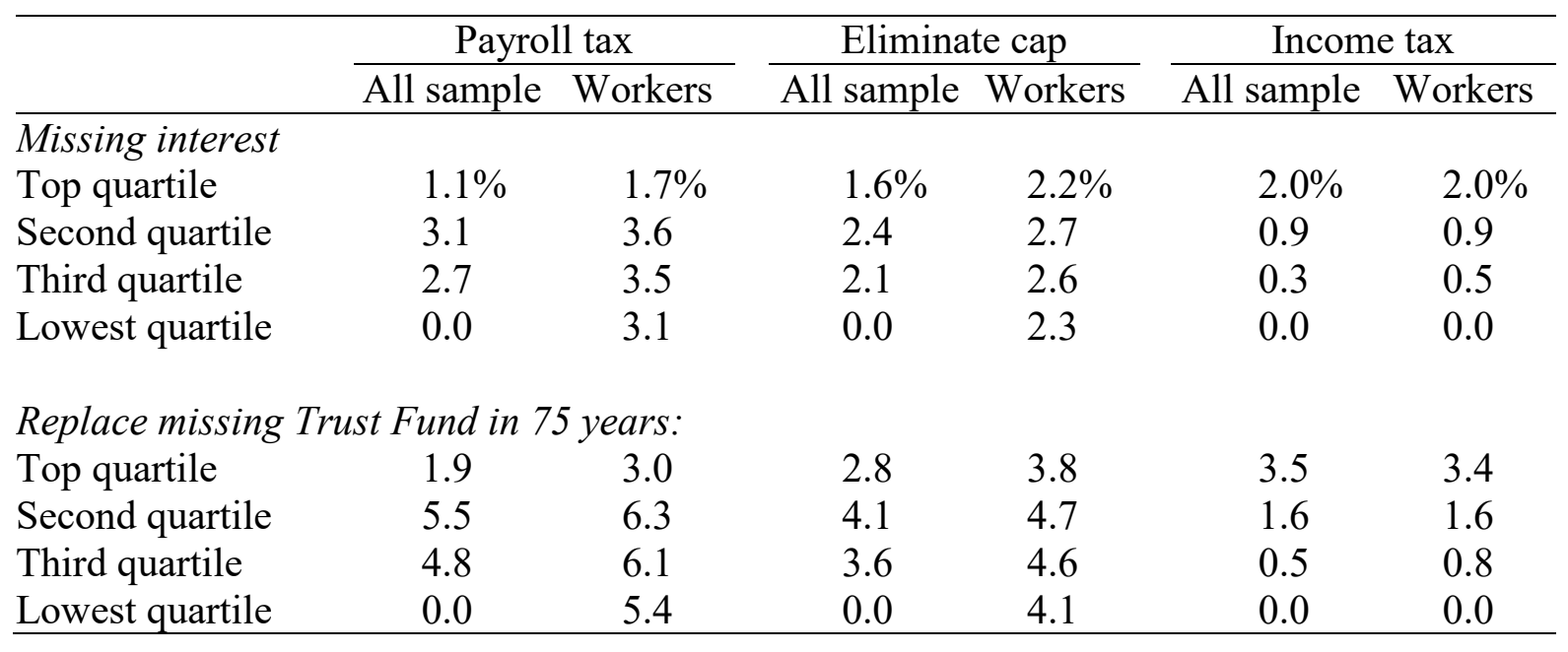

Sources: 2017 Social Security Trustees Report; and authors' calculations using the 2013 SCF and Feenberg and Coutts ("TaxSim"). 
Table 4a. Median Reduction in Utility for Tax Increases, by Income Quartile $(\boldsymbol{\gamma}=\mathbf{2})$

\begin{tabular}{|c|c|c|c|c|c|c|}
\hline & \multicolumn{2}{|c|}{ Payroll tax } & \multicolumn{2}{|c|}{ Eliminate cap } & \multicolumn{2}{|c|}{ Income tax } \\
\hline & All sample & Workers & All sample & Workers & All sample & Workers \\
\hline \multicolumn{7}{|l|}{ Missing interest } \\
\hline Top quartile & $1.4 \%$ & $2.2 \%$ & $2.0 \%$ & $2.7 \%$ & $2.4 \%$ & $2.4 \%$ \\
\hline Second quartile & 3.5 & 3.9 & 2.7 & 2.9 & 1.0 & 1.0 \\
\hline Third quartile & 2.8 & 3.6 & 2.1 & 2.7 & 0.3 & 0.5 \\
\hline Lowest quartile & 0.0 & 2.7 & 0.0 & 2.0 & 0.0 & 0.0 \\
\hline \multicolumn{7}{|c|}{ Replace missing Trust Fund in 75 years: } \\
\hline Top quartile & 2.6 & 3.9 & 3.5 & 4.8 & 4.3 & 4.3 \\
\hline Second quartile & 6.4 & 7.1 & 4.8 & 5.3 & 1.8 & 1.8 \\
\hline Third quartile & 4.9 & 6.5 & 3.7 & 4.8 & 0.5 & 0.8 \\
\hline Lowest quartile & 0.0 & 4.8 & 0.0 & 3.6 & 0.0 & 0.0 \\
\hline
\end{tabular}

Sources: 2017 Social Security Trustees Report; and authors' calculations using the 2013 SCF and Feenberg and Coutts ("TaxSim").

Table 4b. Median Reduction in Utility for Tax Increases, by Income Quartile $(\boldsymbol{\gamma}=\mathbf{3})$

\begin{tabular}{|c|c|c|c|c|c|c|}
\hline & \multicolumn{2}{|c|}{ Payroll tax } & \multicolumn{2}{|c|}{ Eliminate cap } & \multicolumn{2}{|c|}{ Income tax } \\
\hline & All sample & Workers & All sample & Workers & All sample & Workers \\
\hline \multicolumn{7}{|l|}{ Missing interest } \\
\hline Top quartile & $2.9 \%$ & $4.5 \%$ & $4.0 \%$ & $5.5 \%$ & $4.9 \%$ & $4.8 \%$ \\
\hline Second quartile & 5.6 & 8.0 & 5.4 & 6.0 & 2.0 & 2.1 \\
\hline Third quartile & 6.1 & 7.3 & 4.2 & 5.4 & 0.6 & 1.0 \\
\hline Lowest quartile & 0.0 & 5.4 & 0.0 & 4.1 & 0.0 & 0.0 \\
\hline \multicolumn{7}{|c|}{ Replace missing Trust Fund in 75 years: } \\
\hline Top quartile & 5.2 & 8.0 & 7.1 & 9.9 & 8.8 & 8.8 \\
\hline Second quartile & 13.2 & 14.7 & 9.7 & 10.9 & 3.6 & 3.7 \\
\hline Third quartile & 10.1 & 13.3 & 7.5 & 9.9 & 1.1 & 1.7 \\
\hline Lowest quartile & 0.0 & 9.8 & 0.0 & 7.3 & 0.0 & 0.0 \\
\hline
\end{tabular}

Sources: 2017 Social Security Trustees Report; and authors' calculations using the 2013 SCF and Feenberg and Coutts ("TaxSim"). 


\section{Appendix A. Contributions Required in Fully Funded System}

Table A1. Income, Contributions, and Total Assets for Median Worker Contributing 10.6 Percent of Assets to Funded System

\begin{tabular}{ccccc}
\hline Age & Income & Contributions & Interest on assets & Total assets \\
\hline 22 & $\$ 26,400$ & $\$ 2,798$ & -- & $\$ 2,798$ \\
23 & $\$ 26,400$ & $\$ 2,798$ & $\$ 76$ & $\$ 5,672$ \\
24 & $\$ 26,400$ & $\$ 2,798$ & $\$ 153$ & $\$ 8,624$ \\
25 & $\$ 26,400$ & $\$ 2,798$ & $\$ 233$ & $\$ 11,655$ \\
26 & $\$ 29,096$ & $\$ 3,084$ & $\$ 315$ & $\$ 15,054$ \\
27 & $\$ 31,689$ & $\$ 3,359$ & $\$ 406$ & $\$ 18,820$ \\
28 & $\$ 33,923$ & $\$ 3,596$ & $\$ 508$ & $\$ 22,924$ \\
29 & $\$ 35,955$ & $\$ 3,811$ & $\$ 619$ & $\$ 27,354$ \\
30 & $\$ 37,690$ & $\$ 3,995$ & $\$ 739$ & $\$ 32,087$ \\
31 & $\$ 39,289$ & $\$ 4,165$ & $\$ 866$ & $\$ 37,118$ \\
32 & $\$ 40,790$ & $\$ 4,324$ & $\$ 1,002$ & $\$ 42,444$ \\
33 & $\$ 42,145$ & $\$ 4,467$ & $\$ 1,146$ & $\$ 48,057$ \\
34 & $\$ 43,437$ & $\$ 4,604$ & $\$ 1,298$ & $\$ 53,959$ \\
35 & $\$ 44,799$ & $\$ 4,749$ & $\$ 1,457$ & $\$ 60,165$ \\
36 & $\$ 45,960$ & $\$ 4,872$ & $\$ 1,624$ & $\$ 66,661$ \\
37 & $\$ 47,280$ & $\$ 5,012$ & $\$ 1,800$ & $\$ 73,473$ \\
38 & $\$ 48,484$ & $\$ 5,139$ & $\$ 1,984$ & $\$ 80,596$ \\
39 & $\$ 49,616$ & $\$ 5,259$ & $\$ 2,176$ & $\$ 88,031$ \\
40 & $\$ 50,673$ & $\$ 5,371$ & $\$ 2,377$ & $\$ 95,779$ \\
41 & $\$ 51,796$ & $\$ 5,490$ & $\$ 2,586$ & $\$ 103,856$ \\
42 & $\$ 52,938$ & $\$ 5,611$ & $\$ 2,804$ & $\$ 112,271$ \\
43 & $\$ 54,051$ & $\$ 5,729$ & $\$ 3,031$ & $\$ 121,032$ \\
44 & $\$ 55,182$ & $\$ 5,849$ & $\$ 3,268$ & $\$ 130,149$ \\
45 & $\$ 56,131$ & $\$ 5,950$ & $\$ 3,514$ & $\$ 139,613$ \\
46 & $\$ 56,941$ & $\$ 6,036$ & $\$ 3,770$ & $\$ 149,419$ \\
47 & $\$ 57,813$ & $\$ 6,128$ & $\$ 4,034$ & $\$ 159,581$ \\
48 & $\$ 58,542$ & $\$ 6,205$ & $\$ 4,309$ & $\$ 170,095$ \\
49 & $\$ 59,068$ & $\$ 6,261$ & $\$ 4,593$ & $\$ 180,949$ \\
50 & $\$ 59,278$ & $\$ 6,283$ & $\$ 4,886$ & $\$ 192,118$ \\
51 & $\$ 59,430$ & $\$ 6,300$ & $\$ 5,187$ & $\$ 203,605$ \\
52 & $\$ 59,414$ & $\$ 6,298$ & $\$ 5,497$ & $\$ 215,400$ \\
53 & $\$ 59,056$ & $\$ 6,260$ & $\$ 5,816$ & $\$ 227,476$ \\
54 & $\$ 58,514$ & $\$ 6,203$ & $\$ 6,142$ & $\$ 239,820$ \\
55 & $\$ 57,668$ & $\$ 6,113$ & $\$ 6,475$ & $\$ 252,408$ \\
56 & $\$ 56,277$ & $\$ 5,965$ & $\$ 6,815$ & $\$ 265,189$ \\
57 & $\$ 55,020$ & $\$ 5,832$ & $\$ 7,160$ & $\$ 278,181$ \\
58 & $\$ 53,433$ & $\$ 5,664$ & $\$ 7,511$ & $\$ 291,356$ \\
59 & $\$ 51,801$ & $\$ 5,491$ & $\$ 7,867$ & $\$ 304,713$ \\
60 & $\$ 49,642$ & $\$ 5,262$ & $\$ 8,227$ & $\$ 318,202$ \\
61 & $\$ 47,061$ & $\$ 4,988$ & $\$ 8,591$ & $\$ 331,782$ \\
62 & $\$ 45,828$ & $\$ 4,858$ & $\$ 8,958$ & $\$ 345,598$ \\
63 & $\$ 44,622$ & $\$ 4,730$ & $\$ 9,331$ & $\$ 359,659$ \\
64 & $\$ 43,444$ & $\$ 4,605$ & $\$ 9,711$ & $\$ 373,975$ \\
65 & $\$ 43,444$ & $\$ 4,605$ & $\$ 10,097$ & $\$ 388,677$ \\
\hline & & & \\
\hline & & & & \\
& & & & \\
& & & & \\
& & & &
\end{tabular}

Average income: $\$ 48,625$

Income from assets at 4.5 percent annuity: $\$ 17,490$

Replacement rate at age $65: 36.0 \%$

Note: Assumes interest rate of 2.7 percent. Earnings profile based on Social Security's Scaled Earnings Profile. Source: Authors' calculations. 


\section{Appendix B. Comparing Results from Approximation to Leimer (2007)}

One of the primary goals of the calibration method described in the body of this paper is to update estimates of the Missing Trust Fund to reflect the situation today. But the estimates obtained from that method are just that, estimates. Showing that the estimation method presented above results in numbers that closely fit those in Leimer (2007) - which are based on actual data and then projections - would build confidence in the method. To make this comparison, we use the actual numbers reported in Leimer (2007) and put the numbers presented in Figures 1 and 2 into 2001 dollars and 2001 present value to be consistent with the time period used in Leimer (2007). Figures B1 and B2 show the results of this comparison and reveal stark differences. The difference is small for earlier years, but becomes larger for birth cohorts that either had not begun making payments into the program when Leimer's data ended (roughly the 1980 birth cohort) or had not begun receiving payments (roughly the 1940 birth cohort).

This result suggests the issue may simply be in the projections used in the two approaches - Leimer (2007) used projections from the 2000 Social Security Trustees Report, and we use projections from the 2016 Social Security Trustees Report. Indeed, Figure B3 suggests this is likely the case, as after 2000, both the long-run forecasted payroll contributions Social Security was anticipating as well as the benefits it assumed it would have to pay out dropped significantly. If the 2000 Social Security Trustees Report numbers are used and our methodology applied, the Leimer (2007) estimates and our estimates come into line, as is shown in Figures B4 and B5.

In short, the approximation method used seems to reflect fairly well what one would get using actual data. 
Figure B1. Present Value of Payroll Tax Contributions by Birth Cohort, 2001 Dollars

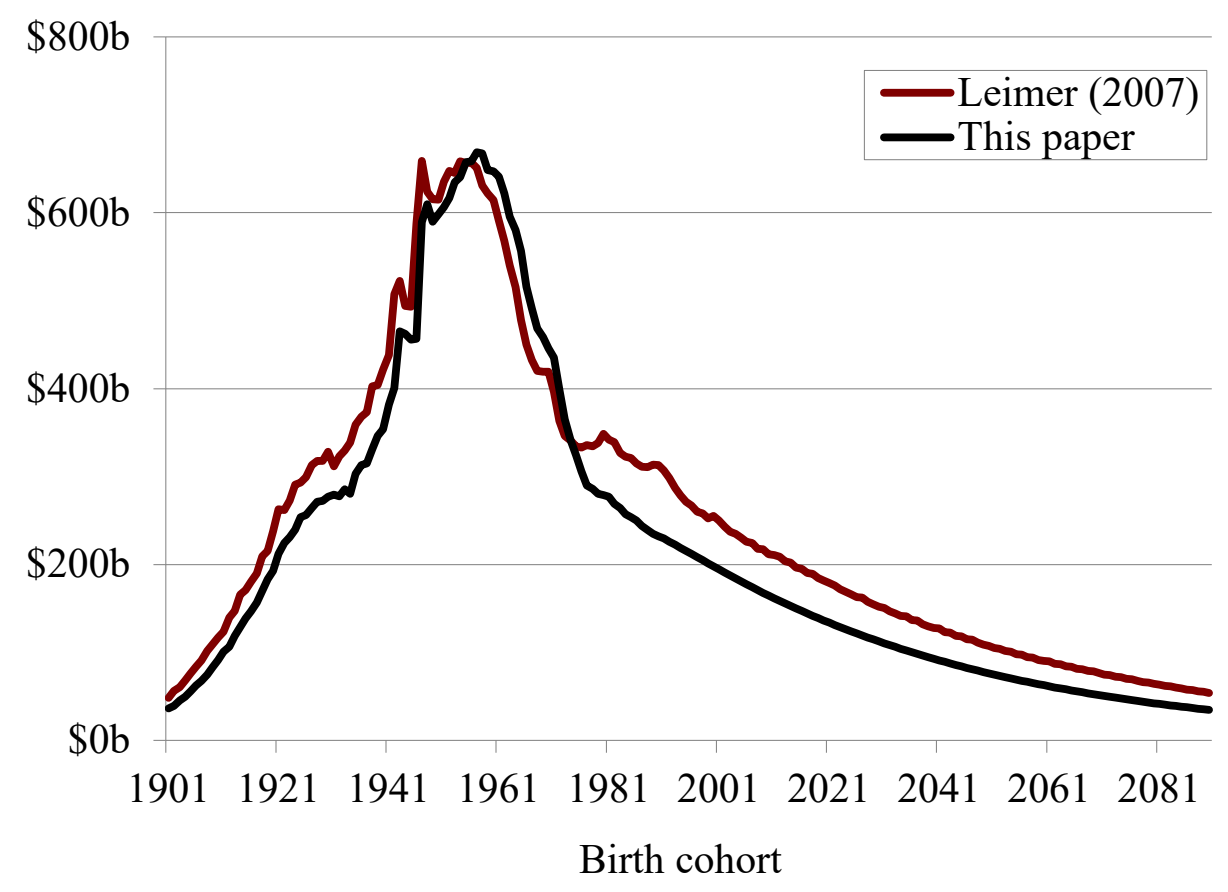

Sources: 2017 Social Security Trustees Report; Leimer (2007); and authors' calculations.

Figure B2. Present Value of Benefits by Birth Cohort, 2001 Dollars

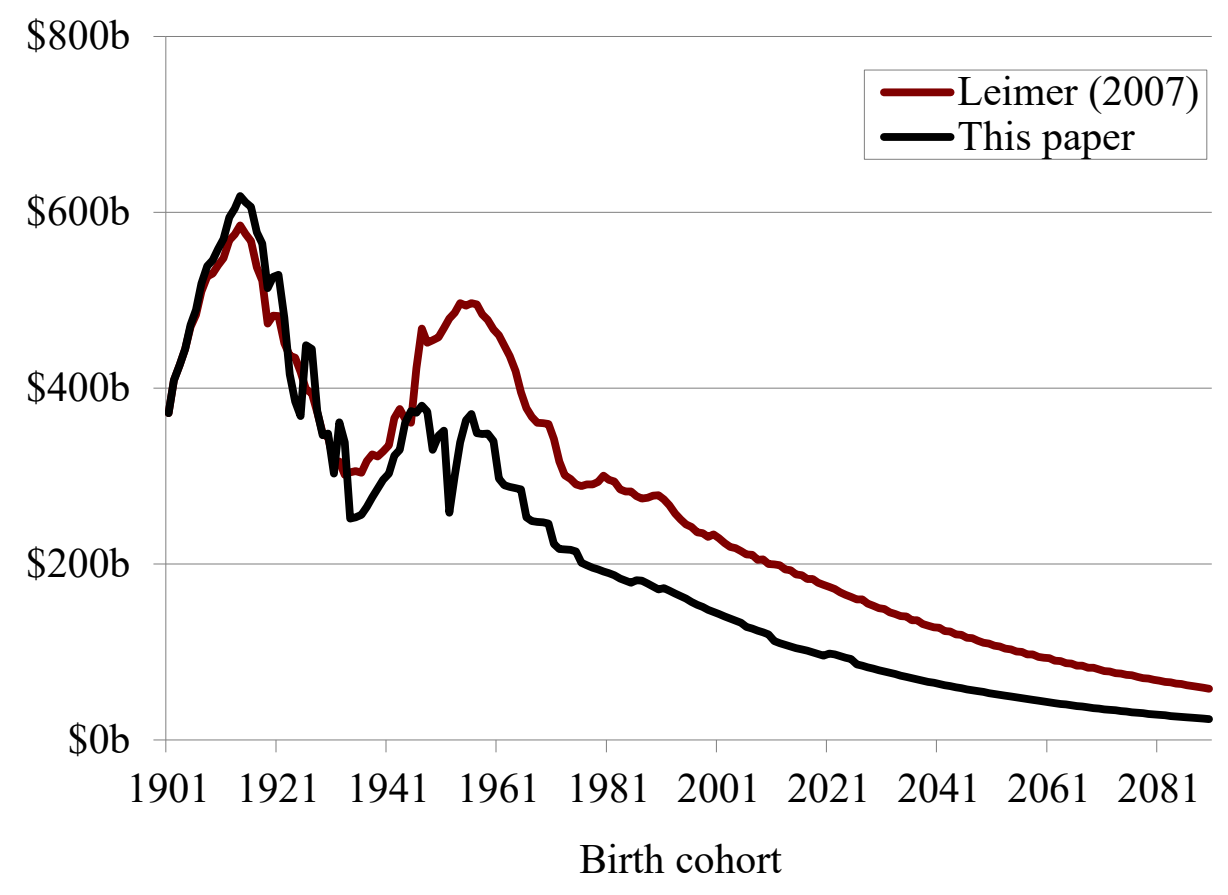

Sources: 2017 Social Security Trustees Report; Leimer (2007); and authors' calculations. 
Figure B3. Evolution of Projected Payroll-Tax Receipts and Benefit Payouts by 2075, by Trustees Report

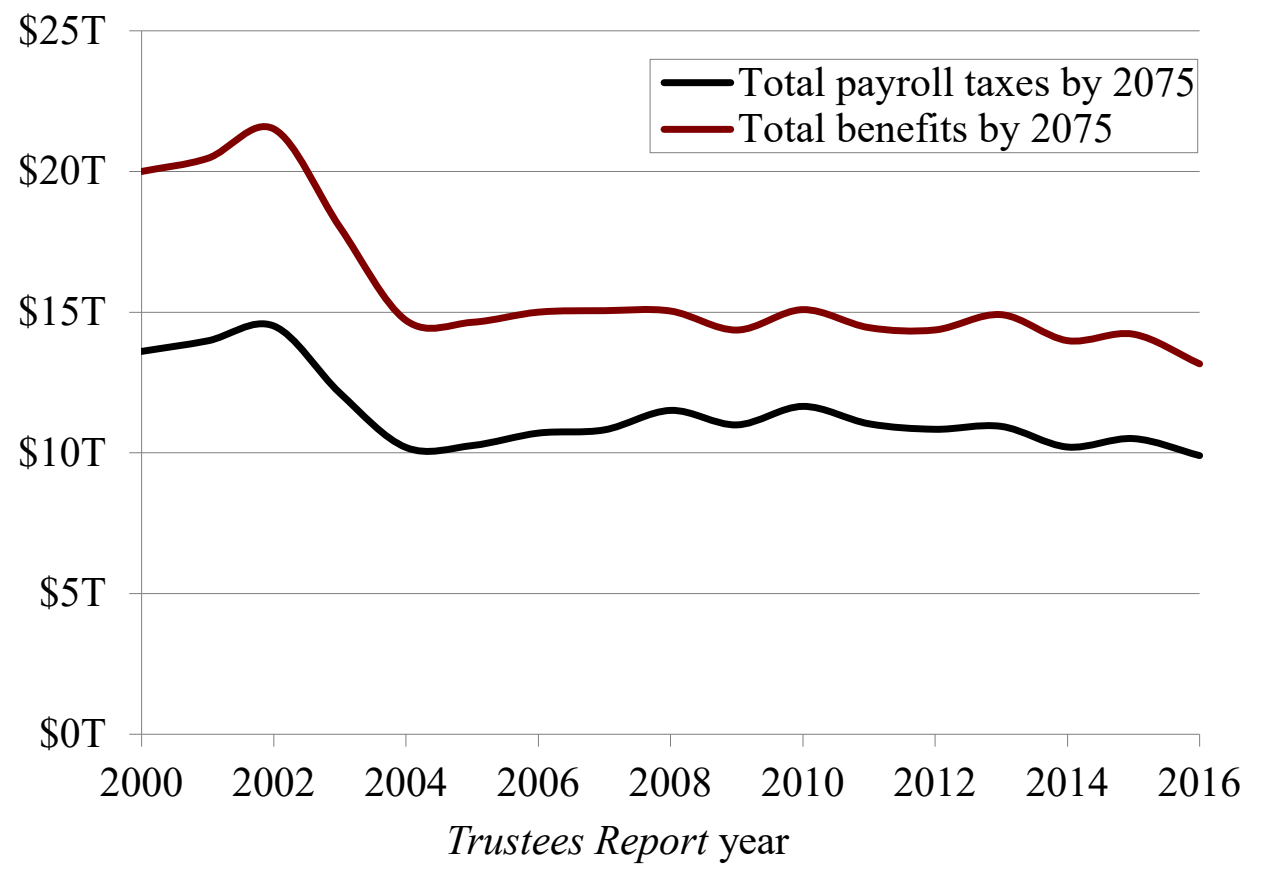

Source: 2000-2017 Social Security Trustees Reports.

Figure B4. Present Value of Payroll Tax Contributions by Birth Cohort, 2001 Dollars

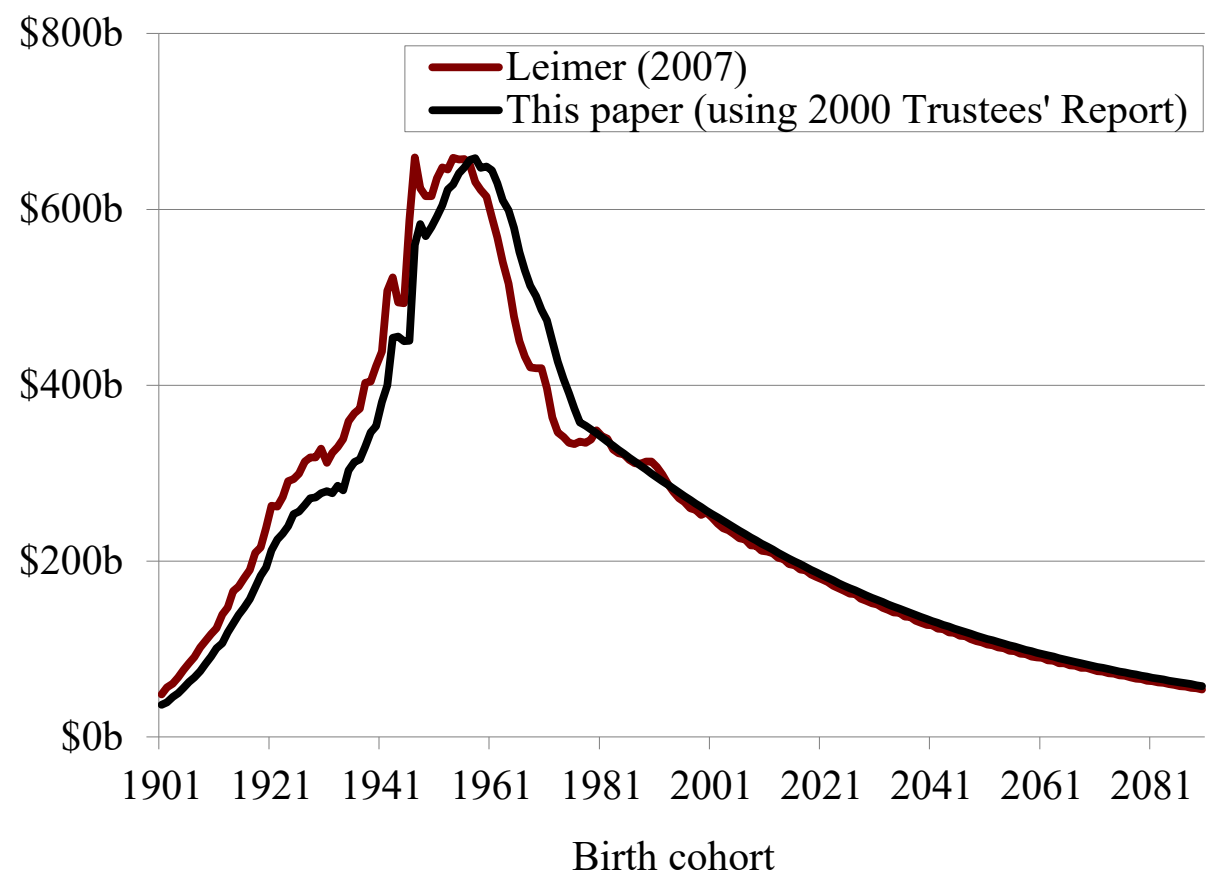

Sources: 2000 Social Security Trustees Report; Leimer (2007); and authors' calculations. 
Figure B5. Present Value of Benefits by Birth Cohort, 2001 Dollars

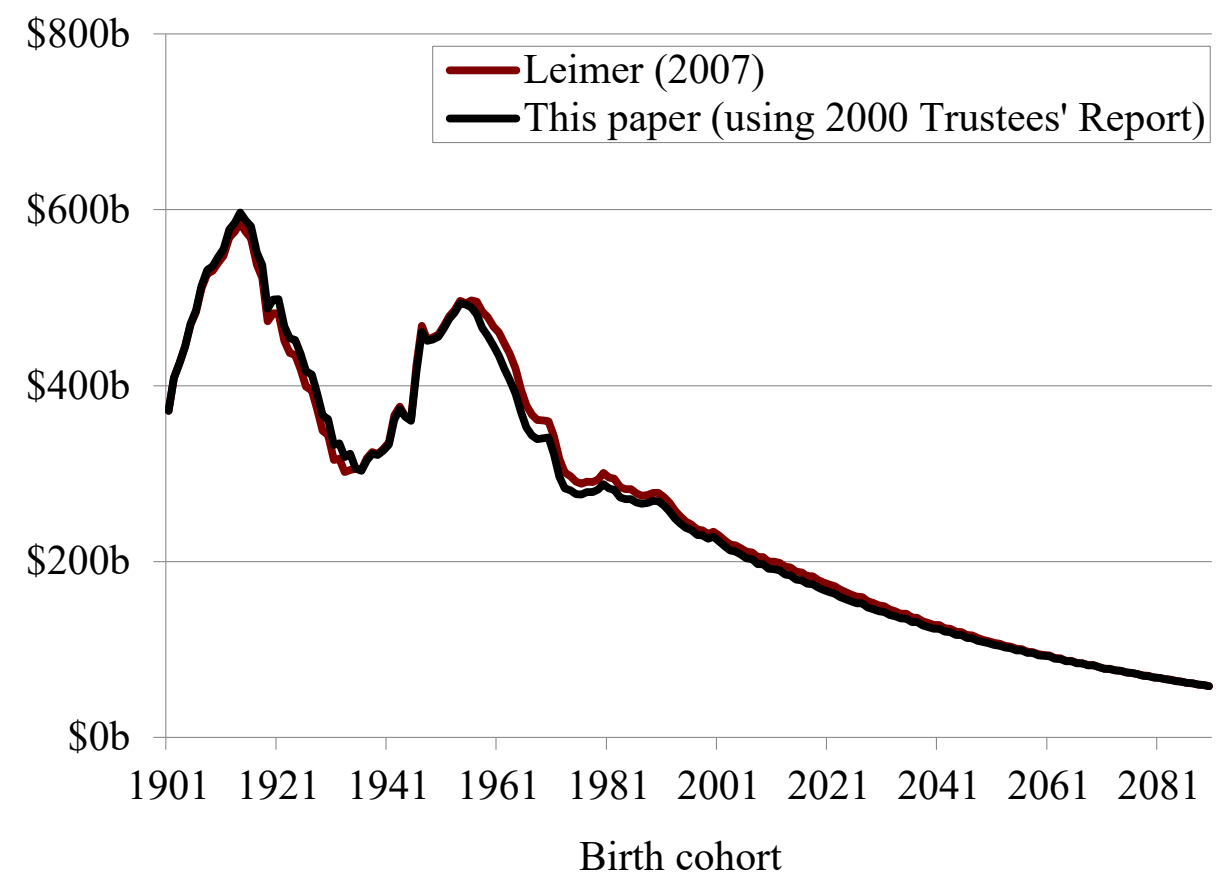

Sources: 2000 Social Security Trustees Report; Leimer (2007); and authors' calculations. 


\section{RECENT WORKING PAPERS FROM THE CENTER FOR RETIREMENT RESEARCH AT BOSTON COLLEGE}

Retirement Prospects for the Millennials: What is the Early Prognosis? Richard W. Johnson, Karen E. Smith, Damir Cosic, and Claire Xiaozhi Wang, November 2017

Mom and Dad We're Broke, Can You Help? A Comparative Study of Financial Transfers Within Families Before and After the Great Recession Mary K. Hamman, Daniela Hochfellner, and Pia Homrighausen, November 2017

Homeownership, Social Insurance, and Old-Age Security in the United States and Europe Stipica Mudrazija and Barbara A. Butrica, October 2017

How Much Does Motherhood Cost Women in Social Security Benefits? Matthew S. Rutledge, Alice Zulkarnain, and Sara Ellen King, October 2017

How Much Does Out-of-Pocket Medical Spending Eat Away at Retirement Income? Melissa McInerney, Matthew S. Rutledge and Sara Ellen King, October 2017

Can Knowledge Empower Women to Save More for Retirement?

Drew M. Anderson and J. Michael Collins, September 2017

Dementia, Help with Financial Management, and Well-Being Anek Belbase and Geoffrey T. Sanzenbacher, September 2017

The Behavioral and Consumption Effects of Social Security Changes Wenliang Hou and Geoffrey T. Sanzenbacher, September 2017

Family Transfers With Retirement-Aged Adults in the United States: Kin Availability, Wealth Differentials, Geographic Proximity, Gender, and Racial Disparities Ashton M. Verdery, Jonathan Daw, Colin Campbell, and Rachel Margolis, August 2017

Guardianship and the Representative Payee Program Anek Belbase and Geoffrey T. Sanzenbacher, August 2017

The Relative Effects of Economic and Non-Economic Factors on Taxpayers' Preferences Between Front-Loaded and Back-Loaded Retirement Savings Plans Andrew D. Cuccia, Marcus M. Doxey, and Shane R. Stinson, July 2017

Social Security and Total Replacement Rates in Disability and Retirement Mashfiqur R. Khan, Matthew S. Rutledge, and Geoffrey T. Sanzenbacher, May 2017

All working papers are available on the Center for Retirement Research website (http://crr.bc.edu) and can be requested bye-mail (crr@bc.edu) or phone (617-552-1762). 